\title{
Socrates and Superiority
}

\author{
Nathan Hanna
}

\begin{abstract}
I propose an alternative interpretation of the Crito. The arguments that are typically taken to be Socrates' primary arguments against escape are actually supplementary arguments that rely on what I call the Superiority Thesis, the thesis that the state and its citizens are members of a moral hierarchy where those below are tied by bonds of obligation to those above. I provide evidence that Socrates holds this thesis, demonstrate how it resolves a number of apparent difficulties, and show why my interpretation is preferable to competing interpretations.
\end{abstract}

\section{Introduction}

Commentary on the Crito usually emphasizes two of its arguments: the argument from injury and the argument from agreement. ${ }^{1} \mathrm{I}$ argue that standard interpretations of these arguments overlook the Socratic commitments they rely on and misunderstand the role they play in Socrates' overall argument against escape. The arguments rely, not on relatively elaborate theories of law, political obligation, or agreement, but on the thesis that states and citizens are members of a moral hierarchy where states have a special, superior status in relation to their citizens. This thesis-the Superiority Thesis-is the principal support for Socrates' decision not to escape. The arguments from agreement and injury also rely on this thesis and, though valid, serve primarily as persuasive supplements to Socrates' fundamental argument: an argument from superiority.

I begin by listing five problems with the arguments of the Crito. Standard interpretations, I claim, fail to adequately

Nathan Hanna is a philosophy student at Syracuse University. His interests include metaethics, political philosophy, and punishment. His dissertation is on the justifiability of punishment. 
resolve these problems. I then extract the Superiority Thesis and the superiority argument from the text and show how they resolve these problems. In proposing this interpretation, I hope to stake out a middle ground between competing interpretations of the Crito and offer a more plausible understanding of the text and of Socrates' moral and political philosophy.

\section{Five Problems}

The Crito presents readers with a variety of problems. I will deal with five. First, there is an apparent inconsistency between what Socrates says in the Apology and what he says in the Crito. ${ }^{2}$ In the Apology Socrates declares his willingness to disobey both state commands to commit injustice and state commands that conflict with divine commands ( $A p .29 \mathrm{~d}, 32 \mathrm{a}-\mathrm{e}$ ). But in the Crito the Laws claim that citizens have an unconditional obligation to obey the state $(\mathrm{Cr} .51 \mathrm{~b}-\mathrm{c}) \mathrm{.}^{3}$

The second problem has to do with injury. Socrates argues that citizens are obligated to obey the state because disobedience is injurious to the state and doing injury is wrong. But it looks like one could injure the state by disobeying the sorts of commands that Socrates is willing to disobey. In certain situations, his principles may leave one with no choice but to do wrong. The most obvious example, presented hypothetically in the Apology, is a case where a state command and a divine command conflict. Obeying God would injure the state and obeying the state would mean disobeying God.

The third problem involves the legitimacy of the state's command. In partial response to Crito's litany of considerations, Socrates dismisses as worthless the opinions of the many, arguing that only expert opinions merit consideration. Socrates' lengthy discussion of the worthlessness of majority opinion $(\mathrm{Cr}$. $46 \mathrm{e}-48 \mathrm{~b}$ ) could be thought to call into question the legitimacy of the verdict against him. The verdict was issued by nonexpert jurors, many of whom came to their decision on the basis of prejudice rather than on the basis of the evidence-in violation of their oath $(\mathrm{Cr} .35 \mathrm{c}-\mathrm{d})$. One might think Socrates' views on the reliability of majority opinion give him reason to think that judicial verdicts issued under such conditions are not legitimate and therefore need not be obeyed.

The fourth and fifth problems stem from the fact that Socrates does not seem to say enough in support of his claims regarding obligation and injury. His claims about obligation give rise to the fourth problem. It is not clear why the agreement between Socrates and the state has the terms Socrates claims it has. Why is it that by remaining in Athens anyone in Socrates' position has thereby agreed to do anything the state commands unless he can persuade it otherwise ( $\mathrm{Cr}$. 51e)? Even if one grants Socrates the existence of an agreement, it is not clear 
why Socrates has the specific obligations that he claims to have. Furthermore, the alleged existence of an agreement seems in tension with Socrates' analogy between citizens and slaves. If citizens are like slaves, appeals to agreement seem out of place (Martin 1970).

The fifth problem is that it is not clear how and why the state would suffer injury as a result of disobedience. Some commentators attempt conceptual analyses of law and appeal to familiar considerations about its universal applicability in order to explain things (e.g., Allen 1972; Farrell 1978; Wade 1971), but there is little textual support for attributing such commitments to Socrates. The passage often thought to suggest something along these lines is at $\mathrm{Cr}$. 50b.

Do you imagine that a city can continue to exist and not be turned upside down, if the legal judgments which are pronounced in it have no force but are nullified and destroyed by private persons?

As a first step toward reinterpreting the Crito, I propose an alternative interpretation of this crucial passage. Before offering my interpretation, however, I will consider a representative sample of attempts to deal with some of the problems I have noted. The deficiencies of these interpretations are instructive and will hopefully serve to motivate my own interpretation.

\section{Contemporary Theory and the Failure of Philosophy}

Perhaps the problem that has given commentators the most persistent difficulty is the problem of inconsistency. How can Socrates' willingness to disobey certain state commands be reconciled with his unqualified claims regarding citizens' obligation of obedience to the state? Commentators have also had an abiding interest in his talk of injury and agreement, seeing in these remarks the seeds of contemporary theories of law and legal obligation. Much effort has been put into spelling out relatively sophisticated theories that commentators think they see working in the background. These efforts, it is assumed, could not only enhance our understanding of the Crito, filling apparent gaps in the arguments and solving other problems, but might even address contemporary concerns about the nature and extent of our legal obligations, the permissibility of civil disobedience, and so on.

Commentators have offered a variety of interpretations of the Crito. Faced with the persistent difficulties and the insufficiency of standard interpretations, some have even denied that the speech of the Laws (the content of which bears primary responsibility for the problems above) reflect Socrates' commitments and contain his own arguments (see, e.g., Brown 1992; 
Congleton 1974; Miller 1996; Young 1974; Weiss 1998). Because the Laws place so much emphasis on obedience and apparently opt for oratorical flair at the expense of valid argument, their speech seems strongly at odds with Socrates' commitment to philosophy. Focusing on the dramatic and literary characteristics of the dialogue, these commentators suggest that the speech of the Laws is meant to take up a task of persuasion, a task that Socrates and philosophy have been unable to achieve. Socrates tries but fails to persuade the unphilosophical Crito with philosophical arguments. Rather than leaving Crito in the lurch, however, Socrates turns things over to the Laws, who successfully persuade Crito by means of the oratory to which he is accustomed. The speech of the Laws is a dramatic device, but it is also, on this interpretation, a means of distancing Socrates from the means used to persuade Crito, who stands as an exemplar of the unphilosophical many.

This interpretation is right to stress the persuasive and dramatic character of the Laws' speech, but many find it too quick to dismiss the speech as unsocratic. Why would Socrates abandon his commitment to philosophical inquiry and opt for oratory in an attempt to persuade Crito? Socrates, after all, consistently expresses distaste for unphilosophical appeals to emotion (e.g., Ap. 17a-c, 35c, 38d-39a; Cr. 50b-c) and throughout the early dialogues exhibits an untiring commitment to philosophical argument in the face of comparable, if not greater, intellectual opacity, not to mention outright hostility-one reason why he was put on trial $(A p .21 \mathrm{~d}-24 \mathrm{~b} ; C r$. 21e-24b; see also Euth. 7c-d). The interpretation, it seems, comes at a rather high cost.

McLaughlin argues that initial preference should be given to the Socratic interpretation: "only after every attempt to give a Socratic interpretation has failed should we conclude that the words of the Laws, which Socrates admits to generally approving, are in fact unsocratic" (McLaughlin 1976, 189). I offer a Socratic interpretation that should have some attractions for proponents of the unsocratic interpretation. Before getting to my interpretation, however, I want to discuss a couple of mainstream, rather well-known Socratic interpretations offered by Allen (1972) and Vlastos (1974).

Allen tries to explain why escape implies injury. The "key," he says, lies in "the nature of judicial authority" (Allen 1972, 564). On this interpretation, Socrates holds that escaping would be tantamount to denying the legitimacy or authority of the judicial verdict against him. Denying the authority of the verdict would be to deny the authority of any verdict. But that would ultimately deny the authority of the law itself since it would deny authority to the application of the law. "Since the application of law is essential to the existence of law, to act in breach of a given application is-by so much-destructive of 
law" (ibid.). This is how Allen interprets $C r$. 50b. Since a city cannot exist without law and law is nothing without application, disobeying the judicial decision is destructive of both the law and the city. This, Allen says, "is essentially a universalization argument" (ibid.). Socrates is working with a principle of legal universalization. Combining this with the principle that it is wrong to do injury, Socrates concludes that escape would be wrong.

As for the possibility that a law or judicial verdict might obligate Socrates to commit injustice, Allen avoids this problem by claiming that "authority extends only so far as agreement binds" (ibid., 565). He thinks that disobeying a state command to commit injustice is not injurious because such commands are not authorized by the agreement between Socrates and the state. The argument from agreement, he claims, "does not serve as an independent ground for refusing to escape: it is rather an essential link in a concatenated argument which rests on the primacy of justice" (ibid., 563). According to Allen, Socrates holds that the existence of an agreement is not the sole grounds for the justice of abiding by it, rather "the justice of abiding by it is a condition for honoring" it (ibid.). Considerations of justice serve as Socrates' fundamental rationale against escape. Hence, the agreement cannot generate an obligation to commit injustice.

Attributing a universalization principle to Socrates is quite speculative and speculation of this sort seems rather undesirable. The text simply does not suggest that Socrates holds such a principle. Even if we set the speculation aside, however, there is a significant problem with Allen's interpretation. He says that doing injury "is treated as a direct implication of the proposition that one is never to do injustice" (ibid., 563). But if the universalization principle applies to laws and judicial verdicts that command the commission of injustice-and Allen gives us no reason to think that it does not (quite the opposite actually)then it looks like disobeying such laws or verdicts injures the state. Agreement seems irrelevant to this problem since it can be generated simply with Allen's claims about the nature of laws and judicial decisions. Since justice requires that one must never inflict injury, it looks like one is obligated and not obligated to obey laws and judicial decisions that command unjust action. Allen's attempt to resolve the first, fourth, and fifth problems fails to resolve the second problem.

Vlastos takes a different approach. Worried primarily about the problem of inconsistency, he focuses on the argument from agreement, elaborating at length on the nature of a tacit agreement-a concept he explicitly, and rather speculatively, attributes to Socrates (Vlastos 1974,525 ). He also strongly emphasizes considerations of gratitude, claiming that Socrates held that receipt of benefits generates obligations of "special forbearance" (ibid., 520) that require one to sacrifice and take 
risks to spare one's benefactors injury. Such obligations, however, do not require one to do just anything on behalf of one's benefactors. "Collisions between duties" (ibid., 530) will sometimes require that one violate the law, as Socrates recognizes in the first book of the Republic and affirms with his professed willingness to disobey. Socrates, Vlastos concludes, is just being careless when he says that citizens have an unconditional obligation to obey the state. Vlastos resolves the inconsistency by taking the speech of the Laws to involve a bit of careless exaggeration.

Like Allen, Vlastos seems to see Socrates' argument as committed first and foremost to justice. Agreements will generate obligations only if those agreements accord with justice (ibid., 527). By accepting the benefits the legal order of Athens affords its citizens, Socrates has entered into an agreement and incurred an obligation of obedience. This duty springs from a rather sophisticated theory of legal obligation. Surprisingly, Vlastos attributes to Socrates a theory of legal obligation that looks identical to the fair play theory of legal obligation proposed by Hart (1955) and Rawls (1964).

The legal order of Athens is an association which produces for all of its citizens great benefits of individual security, welfare, and culture. Law-obedience is the form in which every citizen pays his dues to the collective enterprise. By exercising the rights of citizenship in a state like Athens, he gives his fellows to understand that he agrees to carry his individual share of the aggregate burden, undertakes in all fairness to do his part, as he expects them to do theirs. (Vlastos 1974, 528)

I quote at such length to make a point. It seems highly speculative-speculative to the point of implausibility-to attribute such an elaborate theory of legal obligation to Socrates. Insofar as Vlastos does this he fails to adequately resolve the fourth and fifth problems. Such speculation simply projects contemporary views on the text. It provides no insight on what the text reveals about Socratic commitments. Nowhere does the text remotely suggest that Socrates is working with this theory in mind.

Granted, Vlastos admits that Socrates did not spell this argument out and claims only that Socrates had "an intuitive sense of it" (ibid., 527), but an attempt to explicate, on the basis of fragmentary remarks, what Socrates had an intuitive sense of requires caution. The fact that the Laws say that they have benefited citizens $(\mathrm{Cr}$. 51c) and their analogy between themselves and parents hardly suggests, as Vlastos thinks they do, that Socrates intuitively grasps and is on some level working with the fair play theory of legal obligation. The same goes for Vlastos's theory of tacit consent. 
The unsocratic interpretation, as McLaughlin suggests, should be rejected until every reasonable attempt to give a Socratic interpretation has failed. But Socratic interpretations like the ones Allen and Vlastos give should, I think, also be rejected unless less speculative Socratic interpretations fail. I propose a less speculative Socratic account that resolves the problems that alternative Socratic interpretations have been unable to cope with and that more plausibly frames the relevant arguments within Socrates' overall argument against escape.

\section{Moral Hierarchy}

Let us return to $C r$. $50 \mathrm{~b}$. One might think that the passage expresses some elaborate theory of law or legal obligation. Allen, as we saw, says that there is a universalization argument here. I will try to avoid this sort of speculation.

Throughout the Crito and the Apology, Socrates consistently expresses a concern, not so much for law in particular, but more generally for the state's relationship with-primarily its superior status with respect to-its citizens. An accurate interpretation of the Crito must begin with this fact in mind. Socrates' concern for the law stems from his more general concerns regarding the nature of the relationship between states and citizens. The particular law and the particular judicial decision at issue in the Crito are being discussed under the umbrella of a theory about the relative moral standing of citizens, states, and God (among others), not a theory about the law in particular.

I will set aside the passage's talk of the destruction of the law for a moment and focus on something else. The passage hints at something about the relationship between the state and "private persons." In explicitly mentioning private persons as it does, the passage reflects a thesis about the relationship between citizens and the state-that it is a relationship between unequal parties, between parties with different moral standing. A few lines below, Socrates argues for this thesis by drawing analogies between the state, parents, and masters.

From $\mathrm{Cr}$. 50e-51c the Laws discuss at length the nature of their relationship with citizens. Citizens are compared with children and slaves. They are said to have a different moral standing than the state and its laws: "do you imagine that what is right for us is equally right for you?" (Cr. 50e). They are said to have an inequality of rights with the state and the Laws just as they have an inequality of rights with their parents: "You [do] not have equality of rights" (ibid.) These inequalities are even more pronounced between citizen and state than they are between child and parent-so much so that the analogy is extended and the relationship between state and citizen is compared to that between master and slave. Socrates sums 
things up with a remark that demonstrates that his concerns extend beyond the law.

Both in war and in the law courts and everywhere else you must do whatever your city and your country command, or else persuade them in accordance with universal justice. $(\mathrm{Cr}$. 51b-c, emphasis added)

This infamous passage reflects a concern, not just with law, but with all kinds of state commands: laws, judicial verdicts, superior officers' orders, and so on. ${ }^{4}$ There is an apparent authoritarian streak here, seemingly inconsistent with what Socrates says elsewhere, but focusing on the apparent authoritarianism of the passage can lead one to overlook what it reflects about the generality of Socrates' concerns. His concerns extend beyond the law to the source of the laws' legitimacy and ultimately to the source of citizens' obligations to the state.

Socrates is concerned with more than just law. This should be obvious enough. What may not be so obvious is the fact that he says a lot to suggest that he is working with a general theory about the relative moral standing of citizens, states, God, and others. This theory informs his views on the obligations that citizens have to the state. Consider some passages from the Apology.

I do know that to do wrong and to disobey my superior, whether God or man, is wicked and dishonorable. (Ap. 29b, emphasis added)

Gentlemen, I am your very grateful and devoted servant, but I owe a greater obedience to God than to you. (Ap. 29d, emphasis added)

These passages illustrate two significant elements of Socrates' view: there are unequal relationships between different types of entities and there are entities that are superior to the state, for example, God, toward whom citizens have more pressing obligations of obedience. Considered jointly, the Crito and the Apology reflect a commitment to a moral hierarchy where those below are tied by bonds of obligation to those above (Martin 1970, 36; Wade 1971, 323). ${ }^{5}$ Socrates clearly sets things out: at the top is God, next the state, next parents, then the citizen. ${ }^{6}$ Nearer the bottom are women, children, and slaves (all are mentioned in unflattering similes throughout the dialogues). There is nothing new in attributing any of this to Socrates. What is new is the role I claim these commitments play in his overall argument against escape and how the arguments from injury and agreement fit into this framework.

Socrates holds that a citizen's obligations to the state stem from the special relationship that states have with their citizens, analogous to the relationships between parents and 
their children and masters and their slaves. To put it simply, the state is Socrates' superior, in relevant respect much like his parent or master, and Socrates is therefore obligated to obey the state. This is Socrates' fundamental argument against escapethe argument from superiority. There is no substantive theory of law or modern theory of political obligation at work in the Crito and the Apology, only a view about the relative moral standing of certain entities and the obligations they have to one another. I argue that the arguments from injury and agreement are in fact supplementary arguments that also rely on the Superiority Thesis and that serve primarily as persuasive supplements to the argument from superiority. First, though, I want to show how appealing to the argument from superiority solves the problems with which I began.

\section{Resolving the Problem of Inconsistency}

I have now outlined the basics of my interpretation. This interpretation is preferable to standard ones because it resolves, with minimal speculation, the five problems with which I began: Socrates seems to make inconsistent statements, there seems the possibility of injuring the state even when disobeying only the sorts of commands that Socrates is willing to disobey, there is no account of why the jurors' faulty decision generates a legitimate command, and there is insufficient basis both for Socrates' claim to have the specific obligations that he thinks he has and for his claim of injury. I consider the problem of inconsistency in this section and leave the remaining problems for the next.

Socrates openly admits his willingness to disobey two kinds of state commands: commands to commit injustice and commands that conflict with divine commands. Yet he also seems to claim at $C r .51 \mathrm{~b}-\mathrm{c}$ that citizens have an unconditional obligation to obey the state. Some commentators try to reconcile this apparent inconsistency by pointing to the distinction between doing injustice and suffering injustice and claiming that the agreement between citizens and the state requires only the latter (e.g., Allen 1972, 566; McLaughlin 1976, 191; Vlastos 1974, 527; Wade 1971, 324). Since Socrates holds that one must never commit injustice, the interpretation goes, he cannot consistently hold that his agreement with the state might require him to commit injustice. As he holds no corresponding principle regarding the suffering of injustice, however, the agreement can require that he suffer injustice. Hence, commands to commit injustice are not covered by the agreement and can be disobeyed. The passage at $\mathrm{Cr}$. 51b-c is simply interpretedand partially dismissed-as a piece of "inflated rhetoric" (Vlastos 1974, 534). 
This interpretation gets some things right. The agreement between Socrates and the state does not require him to commit injustice. But the interpretation overemphasizes the importance of agreement, taking agreement to be a significant source of obligation to the state, and ignores Socrates' views on the relative moral standing of states, citizens, and God. It zeroes in on the distinction between doing and suffering injustice with the sole aim of making Socrates consistent and gives an unsatisfying account of why citizens can be obligated to suffer injustice. In short, it fails to accurately capture what Socrates thinks justice, in large part, consists in. Because the interpretation does not correctly identify the source of Socrates' obligation of obedience, it fails to resolve certain problems, for example, the second and fourth problems.

Allen, as we saw, tries to avoid this result by claiming that agreement limits the scope of authority. He thinks that disobeying a state command to commit injustice is not injurious because such commands are not authorized by the agreement. Here the interpretation reaches its limit. It is mistaken to claim that Socrates thinks that agreement determines the extent of citizens' obligations to the state. This suggests a more modern view that agreement is somehow involved in generating political obligation, justice being merely a restriction on the sorts of obligations that agreement can generate. Such an interpretation overlooks Socrates' analogies. Agreement does not define the extent of obligation in the relationships between parents and children, masters and slaves, or God and human beings, so why would Socrates think that agreement determines the extent of citizens' obligations toward the state, given the comparisons he makes?

Socrates does not think that agreement determines the extent of citizens' obligations towards the state. He thinks that certain entities are superior to others, that the latter have certain general obligations of obedience toward the former and that, other things being equal, disobeying one's superior is wrong-agreement or no agreement. Other things are equal when the demands of a superior accord with the demands of justice. The demands of justice are the only limitation on the obligations generated by unequal moral standing.

The apparent inconsistency is resolved as follows. Socrates holds that when the demands of one's superiors conflict, one must yield to the greater superior so long as it does not command one to commit injustice. Both the citizen and the lesser superior have obligations of obedience toward the greater superior. Other things being equal, then, one must act in accordance with divine commands when they conflict with state commands. Hence, Socrates can consistently refuse to obey the state when it commands him to act contrary to a divine command. 
When commands conflict with preexisting demands of justice, for example when the state commands one to commit injustice, one must act in accordance with justice. Justice places certain limits on the legitimacy of state commands, but, given the superiority of the state, state commands also influence justice to some extent. The commands of superiors can make it unjust to do something that would otherwise not be unjust, but they cannot make it just to do something that is independently unjust. Read in context, $\mathrm{Cr}$. $51 \mathrm{~b}-\mathrm{c}$ is consistent with this interpretation. The commands Socrates discusses require submission to punishments, risking one's life in war and similar acts of personal sacrifice, not unjust acts. $C r$. 51b-c need not be interpreted as a hyperbolic, careless passage, but one where the scope of the universal quantifier is implicitly restricted both by the requirement never to commit injustice and by the context, which emphasizes obligations of personal sacrifice on the part of citizens in service to the state-obligations generated by their inferior position in the moral hierarchy.

To paraphrase Wade, the Superiority Thesis "underlies all the reasoning of the Crito and the Apology" (Wade 1971, 323). It holds the key to an adequate resolution of the problem of inconsistency as well as the other problems I listed at the outset and allows us to properly frame the arguments that are typically taken to be Socrates' primary arguments against escape. The relationship between obligation and justice that Socrates' moral hierarchy involves, though often overlooked, bring the seemingly divergent arguments and strands of thought in the Crito together to form a coherent whole. I will now consider the remaining problems and then go on to show what role the arguments from injury and agreement play in Socrates' overall argument against escape.

\section{The Remaining Problems}

The second problem can be resolved fairly quickly. The second problem is the possibility of injuring the state by disobeying state commands to commit injustice. Many interpretations engage in a good deal of speculation, depart significantly from the text, and ultimately cannot resolve this problem. But the Superiority Thesis offers an obvious out: in obeying a divine command that conflicts with a state command, Socrates would not be injuring the state at all, for he would be obeying a superior greater than the state. ${ }^{7}$ If the state suffers injury it would be suffering at its own hands by having acted contrary to divine command, that is, contrary to the will of a superior.

The third problem is the questionable legitimacy of a judicial decision rendered according to (worthless) majority opinion. Standard interpretations tend to ignore this problem, perhaps because it is assumed that the arguments from injury and 
agreement address it. Given the way standard interpretations take these arguments, however, this is not the case. The argument from injury offers no help because it does not establish legitimacy. Legitimacy is usually taken to be a necessary condition for injury: "injury arises only from breach of authority" (Allen 1972, 565).

But the argument from agreement does not seem helpful either. If considerations of justice constrain what can legitimately be agreed to, then the unjust tendencies of majority decisions may not make them suitable candidates for binding agreement. What we need to ask, I think, is what Socrates thinks justice consists in. Commentators tend to work with a relatively underspecified account, taking the relevant principles of justice to be the one forbidding injury and the one enjoining adherence to one's agreements. Neither of these is sufficient here. Socrates, I think, has to appeal to the Superiority Thesis and the obligation to obey one's superiors. The need for this appeal, given the inability of the arguments from injury and agreement to solve this and the other problems, leads me to conclude that the state's superior moral standing actually precedes the agreement. Though it may seem paradoxical to contemporary readers, I will argue that the agreement is a product of the state's superiority and of the related general obligation of obedience citizens have to the state-not a source of them.

Appealing to the Superiority Thesis immediately solves the third problem because it simply renders the state's use of nonexpert jurors appropriate. The state has the moral standing to use this sort of method and even if there are more reliable methods, the state can legitimately use this method in virtue of its superior status. The method may err, but state commands based on it are no less legitimate.

Now for the fourth and fifth problems: the nature of the agreement and the grounds of injury. When it comes to injury, standard interpretations deviate from the text, speculate significantly, and so fail to offer an adequate account of injury. As for agreement, standard interpretations also engage in significant speculation, fail to explain why Socrates has the obligations he thinks he has, and leave the tension between his talk of agreement and his citizen-slave analogy intact.

I will deal with the agreement problem first. The Superiority Thesis licenses a literal reading of $\mathrm{Cr}$. 51e.

If any one of you stands his ground when he can see how we administer justice and the rest of our public organization, we hold that by so doing he has in fact undertaken to do anything that we tell him. ( $\mathrm{Cr} .51 \mathrm{e}$, emphasis added)

From its superior position the state generously deigns to give citizens a choice: they can either leave or agree to abide by 
state commands. The state is not arguing for the existence of an agreement here-it is pointing out the fact that it has created one, with terms it has laid down. The agreement is a product of the state's superiority and of citizens' obligations of obedience to the state, not a source of them. The state is entitled to be stricter (states that do not allow their citizens to leave would not be parties to such agreements, however), but it exercises a measure of restraint by engaging citizens in an agreement and soliciting their consent. Because citizens are inferior to the state they have no say over the terms of the agreement, but none of this means that they cannot enter into one (cf. Martin 1970, 36). Because they are given a choice, citizens can properly be said to agree to the state's terms.

The problem of injury is more complicated. Simply claiming that disobeying legitimate commands is injurious would render disobedience of divine commands injurious to God-presumably an intolerable consequence for Socrates (cf. Wade 1971, 319). But an account that omits any reference to the legitimacy of commands might render defiance of illegitimate commands injurious-another unpalatable result. So the problem calls for some finesse.

I suggest that Socrates is thinking as follows: much of a state's power rests upon its perceived legitimacy (one reason, perhaps, why the speech of the Laws has such a rhetorical flair), and a state cannot continue to survive without its power. Anything that undermines the appearance of the state's legitimacy, anything that undermines reverence of the state and the law, injures the state because it undermines the foundations of its power-power the state is entitled to have because of its superiority. Defiance of a direct command is particularly injurious because it sets a bad example, encouraging defiance on the part of others and lowering the state in the eyes of its citizens. The injury can perhaps be plausibly compared to an attack on someone's reputation-defiance of a direct state command in effect challenges or denies the state's superior moral standing. Unlike standard interpretations, which cast Socrates' talk of injury in terms of unrealistic hypotheticals or conditionals or in terms of strained metaphors, this interpretation takes the charges of injury literally.

My alternative interpretation yields a relatively clean solution of the five problems at minimal cost. Though the arguments as interpreted are not plausible to the contemporary reader, they are at least consistent. Little has been attributed to Socrates that does not have some apparent textual support. Rather than inappropriately attributing modern, relatively elaborate theories to him, my interpretation offers something more in line with his remarks in the Crito and the Apology. 


\section{Consequences and Characteristics of the Interpretation}

One crucial consequence of my interpretation, given its emphasis on obedience to superiors, is that it renders Socrates' account more authoritarian than many commentators think (e.g., Kraut 1984; Weiss 1998). On my interpretation, the relative permissiveness of the Athenian state does little more than soften the blow to antiauthoritarian sensibilities. Socrates' remarks about persuading the state help to motivate his arguments, but they are not relevant parts of any argument. Athens is entitled to be stricter; the fact that it is not may generate more admiration and reverence, and may strengthen the emotional appeal of the Laws' speech, but it does little more than reinforce an independently established obligation of obedience. That obligation stems from the state's superiority. Modern readers may be averse to such a claim, but we should be careful not to let our argumentative preferences adversely influence the interpretive project.

Another consequence of my interpretation is that it takes the arguments from injury and agreement to be supplementary arguments. Socrates' fundamental argument against escape is an argument from superiority. That argument relies on the wrongfulness of disobeying a superior and on the superiority of states to their citizens. But Socrates sees that other valid, though perhaps more persuasive, arguments can be given that rest on the same basic claims. The arguments from injury and agreement do not generate the obligation to obey the state. At best, they seem to reinforce a preexisting obligation. The obligation to obey one's superiors plays a fundamental role. Without it, Socrates' claims regarding injury and agreement would be less secure, perhaps unfounded.

The supplementary, persuasive nature of the arguments from injury and agreement do not render them any less important to the dialogue, however. The unsocratic interpretation, I think, is correct to stress the dramatic nature of the Crito and its evident concern with persuasion. The Crito, after all, is unique among the Platonic dialogues in that Socrates turns things over to an apparent mouthpiece-the Laws-to do his arguing for him. It is mistaken, however, to assume that the Laws and Socrates are at odds so long as there is a reasonable interpretation that can reconcile the two. The use of the personified Laws and their obvious concern with persuasion is not evidence that Socrates wanted to distance himself from what they say (or that Plato wanted to distance Socrates from what they say); rather, it is perfectly understandable given the circumstances of the dialogue. There is a way for proponents of the Socratic interpretation to account for the dialogue's unique characteristics. 
If Socrates has failed to persuade someone, as the unsocratic interpretation holds, it is not Crito but, rather, the people of Athens, whose prejudice toward him he was unable to overcome with his defense. The speech of the Laws puts Socrates' arguments on display, temporarily freed from any displeasing association with him, any distracting hint of immorality, arrogance, or self-indulgence, and powerfully drives home to the reader the injustice of the verdict and the moral carelessness and ignorance of the many who rendered it. As the Laws tell Socrates: "you will leave this place, when you do, as the victim of a wrong done not by us, the laws, but by your fellow men" (Cr. 54b-c). When the Laws say this, they are not pointing out something relevant to the various arguments for obedience but, rather, emphasizing that it was the people of Athens who unjustly convicted Socrates. They are doing what Socrates always did: pointing out people's mistakes, moral failings, and intellectual shortcomings and trying to motivate people toward reflection and self-examination. Most importantly, perhaps, they are calling on people to exercise political and moral responsibilityto respect the law by obeying it, to morally evaluate the law and work to change it by means of rational argument when they find it lacking, and to justly apply it.

The speech of the Laws is a dramatic device, but also a philosophical one. It is meant to persuade but also to achieve objectivity. The arguments the Laws give are meant to persuade, but to persuade in a certain kind of way-through valid argument aimed at revealing the truth and guiding conduct for the better. As Allen (1972) correctly observes, the Crito embodies Socrates' vision of philosophical rhetoric-a powerfully convincing yet philosophically respectable mode of argument.

\section{Conclusion}

By accounting for Socrates' views on the hierarchical relationship between the relevant entities and properly framing the arguments from injury and agreement within this understanding, my interpretation solves the persistent difficulties commentators have encountered in trying to reconcile Socrates' claims with the speech of the Laws and provides a fuller account of Socrates' political and moral commitments. It also stakes out an attractive middle ground between Socratic and unsocratic interpretations. These characteristics, I think, make it preferable to alternative interpretations.

Perhaps readers are inclined to dismiss this as just another ill-conceived interpretation that gives too much credit to a text lacking in argumentative sophistication. Most readers are likely to acknowledge that something akin to the Superiority Thesis is working in the background, at the very least influencing Socrates' thought. Such a claim seems almost trivial given his 
talk of superiority. I have pressed a stronger claim however: that Socrates intentionally grounds the arguments from injury and agreement in the Superiority Thesis. In doing this I risk inviting the charge that I am naively assuming a greater unity and clarity of thought than is merited given the oratorical flair of the Apology and the Crito. But I think Socrates says enough to support the claim that he is actively working with this thesis. If forced to choose, I would be more likely to abandon the charitable stance that Socrates' arguments are coherent than I would be to abandon the claim that the Superiority Thesis underlies much of his thought. At the very least, I hope I have managed to establish that focusing exclusively on the arguments from injury and agreement overlooks a crucial theme and substantially limits our understanding of the Crito and of Socrates' moral and political philosophy. ${ }^{8}$

\section{Notes}

${ }^{1}$ Many, including Allen (1972) and Farrell (1978), see these as the two primary arguments against escape. Some identify more arguments, however. Martin (1970) identifies three: the two mentioned above as well as what he calls an argument from piety involving the analogies between states, parents, and masters. Young adds to these three an argument based on the "effects of Socrates' flight" (Young 1974, 12-13), including the risks his friends would run, such as banishment and loss of property. Vlastos (1974), Walker (1988), and Woozley (1979), among others, identify an argument from gratitude. Vlastos takes this argument and the argument from agreement to be the two primary arguments against escape. Later (in note 4) I argue that, if Socrates does make an argument from gratitude, it should be taken as a supplementary argument. On my interpretation, Socrates talks of benefits partly in order to establish the state-parent analogy, an analogy he uses to ground an argument much like the argument from piety: the argument from superiority.

${ }^{2}$ Many of the problems I deal with in this section stem from the speech of the Laws. For simplicity's sake, I will, in this section, simply attribute everything the Laws say to Socrates. There are some interpretive complications that I will deal with later, however.

${ }^{3}$ This is perhaps the most widely noted problem. Commentators have put a great deal of effort into resolving the apparent inconsistency. See, among many others, Allen (1972), Bostock (1990), Brickhouse and Smith (1984), and Vlastos (1974).

${ }^{4}$ The surrounding text is sometimes taken to be pressing an argument from gratitude (see note 1 ). Given the Laws' claim that Socrates' escape would wrong his "guardians" $(\mathrm{Cr} .51 \mathrm{e})$, and the fact that they go out of their way to distinguish this from the wrong Socrates would do by disobeying his parents and violating his agreement, it seems plausible to take their appeal to benefits to be speaking against escape. Considerations of reciprocity may, as Vlastos suggests, be relevant. But it is unlikely that these considerations can do much to secure all the obligations that Socrates claims to have. There is another aspect of the appeal to benefits that should be noted. 
The Laws tell Socrates: "since you have been born and brought up and educated, can you deny, in the first place, that you were our child and servant, both you and your ancestors? And if this is so, do you imagine that what is right for us is equally right for you, and that whatever we try to do to you, you are justified in retaliating?" $(\mathrm{Cr} .50 \mathrm{e})$. This passage suggests that reference to benefits is being used in an argument from analogy whose conclusion is that the relationship between citizen and state is morally like that between child and parent. This conclusion then licenses the claim that a citizen's obligations to the state are like those of a child to his parent. Nowhere is it suggested that obligations to one's parents are based fundamentally on receipt of benefits and considerations of reciprocity. The obligations are rooted in the fact that these are relationships between unequal parties. If Socrates does make an argument from gratitude, appealing to considerations of reciprocity in order to reveal obligations, such an argument seems merely to reinforce obligations derived from the Superiority Thesis and the argument from superiority. An argument from gratitude would also, then, be a supplementary one.

${ }^{5}$ Martin recognizes that Socrates' analogy between the state and one's master has hierarchical implications, but he mentions this to reinforce the problem of inconsistency, using the Laws' commitment to hierarchy to show how at odds their speech is with Socrates' willingness to disobey. Wade, on the other hand, says that the implied hierarchy strengthens the arguments from agreement and injury but he does little to show exactly how it does this. In fact, he begins by offering a standard interpretation involving conceptual analyses of law to make sense of the argument from injury (Wade 1971, 314-16). His appeal to hierarchy is almost an afterthought. I try to explain things more fully, dispensing as far as possible with speculation and putting the hierarchy at center stage.

${ }^{6}$ One might think that, since the Laws speak in the past tense when establishing the parent-child analogy $(\mathrm{Cr} .50 \mathrm{e}-51 \mathrm{a})$, an adult child is on equal footing with his parents. But the use of the past tense seems simply to be for emphasis, perhaps because a young child has a greater inequality of rights with his parents, which would make that relationship more like that between citizen and state. Socrates' incredulity at Euthyphro's prosecution of his father (Euth. 4a-c) suggests that Socrates thinks that even an adult child still has an unequal relationship with his parents.

${ }^{7}$ Wade appeals to the moral hierarchy in order to resolve the second problem. He does not explain why obeying the greater superior does not injure the state, however (Wade 1971, 320, 323-24).

${ }^{8}$ Many thanks to John Robertson for helpful comments on an earlier draft of this paper.

\section{References}

Allen, R. E. 1972. Law and justice in Plato's Crito. Journal of Philosophy 69:557-67.

Bostock, D. 1990. The interpretation of Plato's Crito. Phronesis 35:120.

Brickhouse, T., and N. Smith. 1984. Socrates and obedience to the law. Apeiron 18:10-18. 
Brown, H. 1992. The structure of Plato's Crito. Apeiron 25:67-82.

Congleton, A. 1974. Two kinds of lawlessness. Political Theory 2:43246.

Farrell, D. M. 1978. Illegal actions, universal maxims, and the duty to obey the law: The case for civil authority in the Crito. Political Theory 6:173-89.

Hart, H. L. A. 1955. Are there any natural rights? Philosophical Review 64:175-91.

Kraut, R. 1984. Socrates and the state. Princeton: Princeton University Press.

Martin, R. 1970. Socrates on disobedience to law. Review of Metaphysics 24:21-38.

McLaughlin, R. 1976. Socrates on political disobedience: A reply to Gary Young. Phronesis 21:185-97.

Miller, M. 1996. 'The arguments I seem to hear': Argument and irony in the Crito. Phronesis 41:121-37.

Rawls, J. 1964. Legal obligation and the duty of fair play. In Law and philosophy, ed. Sidney Hook. New York: New York University Press.

Tredennick, H., trans. 1961a. Crito. In Plato: Collected dialogues, ed. Huntington Cairns and Edith Hamilton. Princeton: Princeton University Press.

Tredennick, H., trans. 1961b. Socrates' defense (Apology). In Plato: Collected dialogues, ed. Huntington Cairns and Edith Hamilton. Princeton: Princeton University Press.

Vlastos, G. 1974. Socrates on political obedience and disobedience. Yale Review 63:517-34.

Wade, F. C. 1971. In defense of Socrates. Review of Metaphysics 25:311-25.

Walker, A. D. M. 1988. Political obligation and the argument from gratitude. Philosophy and Public Affairs 17:191-211.

Weiss, R. 1998. Socrates dissatisfied. New York: Oxford University Press.

Woozley, A. D. 1979. Law and obedience: The arguments of Plato's Crito. Chapel Hill: The University of North Carolina Press.

Young, G. 1974. Socrates and obedience. Phronesis 19:1-29. 